\title{
Correction to: The Bright Side of Grit in Burnout-Prevention: Exploring Grit in the Context of Demands-Resources Model among Chinese High School Students
}

\author{
Ziwen Teuber $^{1} \mathbb{D} \cdot$ Fridtjof W. Nussbeck $^{2} \cdot$ Elke Wild $^{1}$
}

Published online: 22 June 2021

(c) The Author(s) 2021

\section{Correction to: \\ Child Psychiatry \& Human Development \\ (2021) 52:464-476 \\ https://doi.org/10.1007/s10578-020-01031-3}

The article "The Bright Side of Grit in Burnout-Prevention: Exploring Grit in the Context of Demands-Resources Model among Chinese High School Students", written by Ziwen Teuber, Fridtjof W. Nussbeck, Elke Wild, was originally published electronically on the publisher's internet portal (https://link.springer.com/article/10.1007/s10578020-01031-3) on 28 July 2020 without open access. With the author(s)' decision to opt for Open Choice, the copyright of the article changed on 23 May 2021 to () The Author(s) 2021 and the article is forthwith distributed under the terms of the Creative Commons Attribution 4.0 International License (http://creativecommons.org/licenses/by/4.0/), which permits use, duplication, adaptation, distribution and reproduction in any medium or format, as long as you give appropriate credit to the original author(s) and the source, provide a link to the Creative Commons license and indicate if changes were made.

The Open Access funding enabled and organized by Projekt DEAL.

The original article has been corrected.

Open Access This article is licensed under a Creative Commons Attribution 4.0 International License, which permits use, sharing, adaptation, distribution and reproduction in any medium or format, as long as you give appropriate credit to the original author(s) and the source, provide a link to the Creative Commons licence, and indicate if changes were made. The images or other third party material in this article are included in the article's Creative Commons licence, unless indicated otherwise in a credit line to the material. If material is not included in the article's Creative Commons licence and your intended use is not permitted by statutory regulation or exceeds the permitted use, you will need to obtain permission directly from the copyright holder. To view a copy of this licence, visit http://creativecommons.org/licenses/by/4.0/.

Publisher's Note Springer Nature remains neutral with regard to jurisdictional claims in published maps and institutional affiliations.

The original article can be found online at https://doi.org/10.1007/ s10578-020-01031-3.

Ziwen Teuber

zteuber@uni-bielefeld.de

1 Department of Psychology, Bielefeld University,

Universitaetsstr. 25, 33615 Bielefeld, Germany

2 Department of Psychology, University of Konstanz,

Konstanz, Germany 